\title{
Optical-chemical-microphysical relationships and closure studies for mixed carbonaceous aerosols observed at Jeju Island; 3-laser photoacoustic spectrometer, particle sizing, and filter analysis
}

\author{
B. A. Flowers ${ }^{1}$, M. K. Dubey ${ }^{1}$, C. Mazzoleni ${ }^{2}$, E. A. Stone ${ }^{3}$, J. J. Schauer ${ }^{3}$, S.-W. Kim ${ }^{4}$, and S. C. Yoon ${ }^{4}$ \\ ${ }^{1}$ Earth and Environmental Science Division, Los Alamos National Laboratory, Los Alamos, NM 87545, USA \\ ${ }^{2}$ Department of Physics, Michigan Technological University, Houghton, MI 49931, USA \\ ${ }^{3}$ Environmental Chemistry and Technology, University of Wisconsin-Madison, Madison, WI 53706, USA \\ ${ }^{4}$ School of Earth and Environmental Sciences, Seoul National University, Seoul 151-741, South Korea
}

Received: 29 March 2010 - Published in Atmos. Chem. Phys. Discuss.: 14 April 2010

Revised: 28 September 2010 - Accepted: 11 October 2010 - Published: 5 November 2010

\begin{abstract}
Transport of aerosols in pollution plumes from the mainland Asian continent was observed in situ at Jeju, South Korea during the Cheju Asian Brown Cloud Plume-Asian Monsoon Experiment (CAPMEX) field campaign throughout August and September 2008 using a 3-laser photoacoustic spectrometer (PASS-3), chemical filter analysis, and size distributions. The PASS-3 directly measures the effects of morphology (e.g. coatings) on light absorption that traditional filter-based instruments are unable to address. Transport of mixed sulfate, carbonaceous, and nitrate aerosols from various Asian pollution plumes to Jeju accounted for $74 \%$ of the deployment days, showing large variations in their measured chemical and optical properties. Analysis of eight distinct episodes, spanning wide ranges of chemical composition, optical properties, and source regions, reveals that episodes with higher organic carbon (OC)/sulfate $\left(\mathrm{SO}_{4}^{2-}\right)$ and nitrate $\left(\mathrm{NO}_{3}^{-}\right) / \mathrm{SO}_{4}^{2-}$ composition ratios exhibit lower single scatter albedo at shorter wavelengths $\left(\omega_{405}\right)$. We infer complex refractive indices $(n-i k)$ as a function of wavelength for the high, intermediate, and low $\mathrm{OC}_{\mathrm{SO}} \mathrm{S}_{4}^{2-}$ pollution episodes by using the observed particle size distributions and the measured optical properties. The smallest mean particle diameter corresponds to the high $\mathrm{OC} / \mathrm{SO}_{4}^{2-}$ aerosol episode. The imaginary part of the refractive index $(k)$ is greater for the high $\mathrm{OC} / \mathrm{SO}_{4}^{2-}$ episode at all wavelengths. A distinct, sharp increase in $k$ at short wavelength implies enhanced light absorption by OC, which accounts for
\end{abstract}

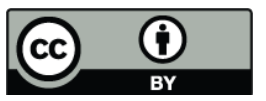

Correspondence to: M. K. Dubey (dubey@lanl.gov)
$50 \%$ of the light absorption at $405 \mathrm{~nm}$, in the high $\mathrm{OC} / \mathrm{SO}_{4}^{2-}$ episode. Idealized analysis indicates increased absorption at $781 \mathrm{~nm}$ by factors greater than 3 relative to denuded black carbon in the laboratory. We hypothesize that coatings of black carbon cores are the mechanism of this enhancement. This implies that climate warming and atmospheric heating rates from black carbon particles can be significantly larger than have been estimated previously. The results of this study demonstrate ways in which atmospheric processing and mixing can amplify particle light absorption for carbonaceous aerosol, significantly at short wavelength, underscoring the need to understand and predict chemical composition effects on optical properties to accurately estimate the climate radiative forcing by mixed carbonaceous aerosols.

\section{Introduction}

Understanding long-range transport (LRT) of pollutants is crucial to inform and implement international and/or regional policies on air-quality (UN-ECE, 2009) and climate change (IPCC, 2007). Outstanding issues include the quantification of aerosol radiative forcing, which depends on composition, mixing state, size, and morphology, as well as the attribution of sources of trans-boundary pollution. Carbonaceous (black carbon and organic carbon, primary and secondary organics, mixed and processed carbon) aerosols found throughout the atmosphere including in large scale Atmospheric Brown Clouds (ABCs) absorb solar radiation, warm the atmosphere, could enhance snow pack and ice sheet melting, and can suppress rainfall over vast polluted regions (Ramanathan and

Published by Copernicus Publications on behalf of the European Geosciences Union. 
Carmichael, 2008). Large scale ABCs are prominent contributors to the continental Asian pollution plume, which entrains regional anthropogenic and natural emissions, whose composition changes with age as it is transported over the Pacific (Dunlea et al., 2009). Optical properties and atmospheric lifetimes of carbonaceous aerosol depend strongly on their size distribution, composition, and mixing state; all of which evolve with age. Therefore, process level understanding of the optical properties of Asian carbonaceous aerosol outflow during its transport across distances up to thousands of kilometers lasting several days is essential to evaluate their radiative forcing of climate. Globally, black carbon aerosols are thought to be the second most important anthropogenic warming influence on climate (Jacobson, 2001; Ramanathan and Carmichael, 2008), and the warming is sensitive to optical properties and mixing state models (Myhre, 2009), both of which are uncertain (IPCC, 2007). It is critical to increase our knowledge of carbonaceous aerosols to inform policy much more precisely on how lowering carbonaceous aerosol emission will reduce global warming, change hydrological cycles, and enhance air quality within weeks of taking actions (Zhang et al., 2009, 2010). More knowledge on carbonaceous aerosol is needed to catalyze their inclusion in the post Copenhagen Accord emissions reductions negotiations which are currently confined to long-lived greenhouse gases. This would also allow the rapidly growing economies in China and India to enhance air quality to improve human health as well as reduce their climate forcing in the short term as they transition to lower carbon-intensive energy and carbon sequestration technologies in the long-term.

Radiative forcing by carbonaceous aerosol is often estimated, in part, using particle mass absorption cross sections (MAC), the wavelength-dependent light absorption coefficient normalized by particle mass in units of $\mathrm{m}^{2} / \mathrm{g}$. Carbonaceous aerosols are operationally defined as mixtures of elemental carbon (EC) or black carbon (BC) and organic carbon (OC) species traditionally determined by thermogravimetric, chemical, and optical analysis of samples collected on filters (Schauer et al., 2003; Chow et al., 2009). Socalled brown carbon $(\mathrm{BrC})$ is a sub-set of $\mathrm{OC}$, delineated by its light absorption at $\mathrm{UV}$ and visible wavelengths (Andreae and Gelencser, 2006). Brown carbon can be directly emitted by combustion, e.g. (Chakrabarty et al., 2010), and can be produced by chemical reactions within the particle after its emission (Hecobian et al., 2010). Calculation of radiative forcing properties for aerosol of any composition is based on its $\operatorname{MAC}(\lambda)$; while the importance of processes influencing $\operatorname{MAC}_{\mathrm{EC}}(\lambda)$ has become recognized recently, including large enhancement of $\mathrm{BC}$ light absorption by coatings observed in laboratory studies, (Bond and Bergstrom, 2006; Cross et al., 2010) mechanistic understanding for $\operatorname{MAC}_{\mathrm{BrC}}(\lambda)$ for carbonaceous aerosol remains poorly constrained. Imaging and chemical analysis of pollution impacted samples demonstrate that mixed black carbon, sulfate, and organic aerosol from biomass and fossil fuel combustion are perva- sive (Adachi and Buseck, 2008; Posfai et al., 1999). Optical properties of such complex carbonaceous aerosol are estimated using idealized treatments of their mixing state - external, internal, or core (Bond et al., 2006; Jacobson, 2001) and depend significantly on approximations which introduce large uncertainties in their forcing. Field observations of optical, chemical, and microphysical properties of mixed carbonaceous aerosol are essential to identify and develop validated relationships to accurately quantify radiative forcing and heating rates in climate models. Developing such relationships from the CAPMEX data set is the goal of our study.

The CAPMEX field campaign was designed to monitor continental outflow from Asia and to observe the effect of Asian emissions (including mixed carbonaceous aerosol from a wide variety of source regions) on atmospheric radiation especially during enforced air quality control periods surrounding the summer 2008 Beijing Olympics (Ramana et al., 2010). In this paper we demonstrate correlations between simultaneous and independent measurements of aerosol optical properties as a function of wavelength and chemical composition at the CAPMEX field site, the Gosan Observatory. The observatory is located on the western side of Jeju Island, a resort island approximately $1100 \mathrm{~km}$ southeast of Beijing; and is not affected by major local industrial pollution sources and has been used to observe continental outflow from Asia for several years (Chen et al., 1997; Topping et al., 2004; Clarke et al., 2004). Distinct plumes undergoing transport from Asia with different chemical composition are delineated and analyzed to show that aerosol light absorption depends strongly upon the $\mathrm{OC} / \mathrm{SO}_{4}^{2-}$ composition, particularly at short wavelengths. Furthermore, we use observed particle size distributions and optical properties to infer an effective mean complex refractive index $(n-i k)$ for ambient carbonaceous aerosol as a function of their $\mathrm{OC} / \mathrm{SO}_{4}^{2-} \mathrm{com}-$ position.

\section{Methods to measure optical properties, composition, and size distributions}

\subsection{3-laser photoacoustic spectrometer}

A 3-laser photoacoustic spectrometer (PASS-3, Droplet Measurement Technologies, Inc., Boulder, CO), a commercial extension of prototypes originally developed at Desert Research Institute and the University of Nevada, Reno (Lewis et al., 2008), was used to measure aerosol absorption and scattering coefficients $\left(\beta_{\text {abs }}\right.$ and $\left.\beta_{\text {sca }}\right)$ at the Gosan Observatory. The PASS- 3 uses 405,532 , and $781 \mathrm{~nm}$ diode lasers aligned in an acoustic resonator and measures aerosol absorption coefficients $\left(\beta_{\text {abs }}\right)$ using the photoacoustic effect. Particle heating by light absorption creates an acoustic wave that is measured by a microphone. The lasers are amplitudemodulated to isolate frequencies close to the resonance frequency of the acoustic cavity, and lock-in detection is used to 
maximize the $\mathrm{S} / \mathrm{N}$ ratio. The instrument simultaneously measures scattering coefficients $\left(\beta_{\text {sca }}\right)$ at the same wavelengths as absorption using a cosine square weighted detector inside the cavity at right angles to the sample flow. This configuration, where both $\beta_{\mathrm{abs}}$ and $\beta_{\mathrm{sca}}$ are measured simultaneously from particles in air, allows for reliable measurement of the aerosol single scatter albedo $\left[\omega=\beta_{\text {sca }} /\left(\beta_{\text {abs }}+\beta_{\text {sca }}\right)\right]$. Regular background measurements (duty cycle $=0.72$ ) are made to allow for background interpolation and correction for laser power drifts during the deployment. The detection limits (10 min signal integration) are $1.5 \mathrm{Mm}^{-1}$ for $\beta_{\mathrm{abs}}$ and $2.0 \mathrm{Mm}^{-1}$ for $\beta_{\mathrm{sca}}$ at $405 \mathrm{~nm}, 2.0 \mathrm{Mm}^{-1}$ for $\beta_{\mathrm{abs}}$ and $3.0 \mathrm{Mm}^{-1}$ for $\beta_{\text {sca }}$ at $532 \mathrm{~nm}$, and $0.15 \mathrm{Mm}^{-1}$ for $\beta_{\text {abs }}$ and $1.0 \mathrm{Mm}^{-1}$ for $\beta_{\text {sca }}$ at $781 \mathrm{~nm}$ (see Supplement for a short description of PASS-3 calibration and performance characteristics and also (Cross et al., 2010) for laboratory comparison). We stress that the PASS-3 measures optical effects of coatings, morphology, and chemistry on light absorption directly that the traditional filter-based sensors fail to do, particularly in polluted environments (Subramanian et al., 2007; Lack et al., 2008).

The $\beta_{\text {sca }}$ at 405 and $781 \mathrm{~nm}$ were used to calculate the intensive Ångström exponent of light scattering $\left(\AA_{\text {sca }}^{405}\right)$, which depends on particle size,

$\AA_{\mathrm{sca}}^{405}=\frac{-\ln \left(\frac{\beta_{\text {sca }}\left(\lambda_{1}\right)}{\beta_{\text {sca }}\left(\lambda_{2}\right)}\right)}{\ln \left(\frac{\lambda_{1}}{\lambda_{2}}\right)}$

where $\lambda_{1}=405 \mathrm{~nm}$ and $\lambda_{2}=781 \mathrm{~nm}$. Smaller particles exhibit larger $\AA_{\text {sca }}^{405}$. In order to diagnose the absorbing component of the aerosol, the Ångström exponent of $\beta_{\text {abs }}$ (defined in complete analogy with (1) but for the absorption coefficient $\beta_{\text {abs }}$ ) at 405 relative to $532 \mathrm{~nm}, \AA_{\text {abs }}(405 / 532)$, as well as $\AA_{\text {abs }}(405 / 781)$, were also calculated. Strong absorption wavelength dependence $\left(\AA_{\mathrm{abs}}>1.6\right)$ indicates organic carbon absorption, e.g. BrC (Bond and Bergstrom, 2006; Gyawali et al., 2009; Lack and Cappa, 2010). Additionally the intensive single scatter albedo $\left(\omega_{\lambda}\right)$ were calculated using,

$\omega_{\lambda}=\frac{\beta_{\mathrm{sca}}(\lambda)}{\beta_{\mathrm{abs}}(\lambda)+\beta_{\mathrm{sca}}(\lambda)}$

where $\lambda$ refers to any one of the PASS-3 laser wavelengths, 781,532 , and $405 \mathrm{~nm}$.

\subsection{Filter analysis of mass and composition}

Elemental carbon (EC) and organic carbon (OC) mass were obtained daily from quartz-based filter measurements at the Gosan Observatory using thermal-optical and chemical methods. 24-h average particulate matter samples were collected for laboratory-based chemical analysis. The commercially fabricated sampler (URG-3000 ABC, URG Corporation, Chapel Hill, North Carolina, USA) was used to collect four $\mathrm{PM}_{2.5}$ samples downstream of two cyclones and four $\mathrm{PM}_{10}$ samples downstream of the $\mathrm{PM}_{10}$ inlet. Sampler flow rates were controlled with the use of a vacuum pump and critical orifices and were measured by a calibrated Rotometer before and after sample collection. Both pre-baked quartz filters ( $47 \mathrm{~mm}$, Tissuquartz, Pall Life Sciences, East Hills, New York, USA) and Teflon membrane filters $47 \mathrm{~mm}$, Teflon Membrane, $2.0 \mathrm{~mm}$ pore size, Pall Life Sciences) were used for sample collection facilitating different chemical measurements. Field blanks were collected over the course of the sampling effort.

One $\mathrm{PM}_{2.5}$ and one $\mathrm{PM}_{10}$ quartz fiber filter were analyzed for elemental carbon and organic carbon (EC and OC) as described by (Schauer et al., 2003) using a common thermaloptical method and protocol. The Teflon filters were weighed before and after sampling to determine particle mass concentrations using a microbalance in a relative humidity and temperature controlled room. Subsequent to final weighing, one $\mathrm{PM}_{2.5}$ and one $\mathrm{PM}_{10}$ Teflon filter were extracted in deionized water and analyzed by ion chromatography for inorganic ions including sulfate ion, nitrate ion, chloride ion, ammonium ion, sodium ion, potassium ion, and calcium ion as described by (Stone et al., 2010). Uncertainties for the organic carbon mass were $\sim 0.20 \mu \mathrm{g} \mathrm{m}^{-3}$ and $\sim 0.15 \mu \mathrm{g} \mathrm{m}^{-3}$ for elemental carbon.

\subsection{Particle size distributions}

The particle number size distributions were measured with two sizing instruments, a scanning mobility particle sizer (SMPS, Model 3034, TSI, Shoreview, MN USA), which includes an on-line condensation particle counter (CPC), and an aerodynamic particle sizer (APS, Model 3321, TSI, Shoreview, MN USA) spectrometer. Particles between 10.4 and $469.8 \mathrm{~nm}$ were measured by the SMPS and the larger particles $(532-19800 \mathrm{~nm})$ were measured by an aerodynamic particle spectrometer (APS), both instruments using logarithmic bin widths of 0.03 . The on-line CPC counted particles with diameters greater than $3 \mathrm{~nm}$.

\subsection{Back trajectories}

NOAA HYSPLIT five-day back-trajectories for each day of the 61 days of the CAPMEX deployment are included in the Supplement to trace the path(s) the air mass had taken to Jeju and to assist in determination of the origin, evolution, and duration of each pollution transport episode (Draxler and Rolph, 2003). We focus on episodes for which we have both optical property and composition data.

\section{Results and discussion}

\subsection{Optical properties}

We expect aerosols undergoing transport from Asia to the Gosan Observatory to be well mixed in aged air masses 


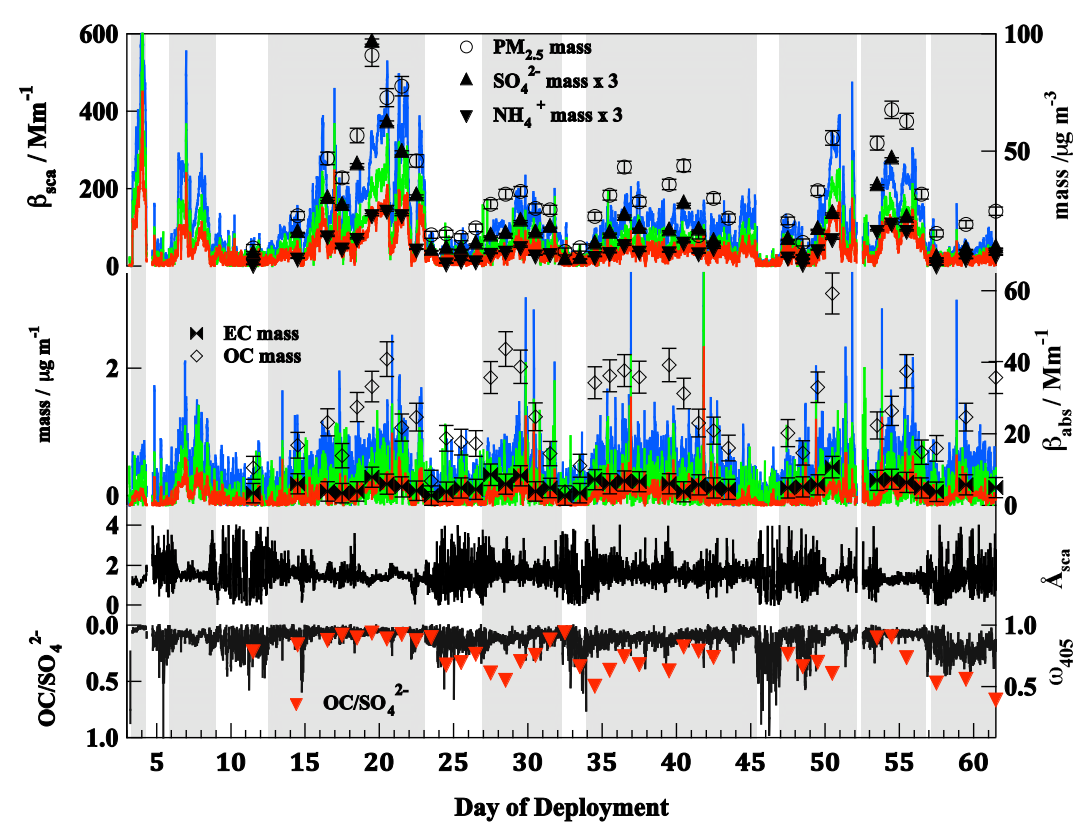

Fig. 1. Temporal profile of aerosol scattering coefficient $\left(\beta_{\text {sca }}\right)$, absorption coefficient $\left(\beta_{\text {abs }}\right)$, scattering Ångström exponent $\left(\AA_{\text {sca }}^{405}\right)$, single scatter albedo at $405 \mathrm{~nm}\left(\omega_{405}\right), \mathrm{PM}_{2.5}$ mass, scaled sulfate and ammonium, and elemental and organic carbon masses $\left(\mu \mathrm{g} \mathrm{m}^{-3}\right)$ for the CAPMEX campaign. The periods highlighted in ash are Asian aerosol transport episodes and their diagnosis as such is discussed in the text. The blue lines represent the $405 \mathrm{~nm}$ data, the green line represents the $532 \mathrm{~nm}$ data, and the red line represents the $781 \mathrm{~nm}$ data.

where atmospheric processing over several days likely increases internal mixing of the aerosol components thereby producing more uniform intensive optical properties. The continuous 10-min average observations of $\beta_{\text {sca }}$ and $\beta_{\text {abs }}$ at 405,532 , and $781 \mathrm{~nm}$, the calculated $\left(\AA_{\mathrm{sca}}^{405}\right)$ and $\omega_{405}$ for the CAPMEX deployment are shown in Fig. 1 and are used to separate Asian transport from local pollution episodes. The definition of the pollution episodes is verified by analyzing the back-trajectories for each episode.

In Fig. 1, aerosols arriving at Jeju during the periods highlighted in ash show enhanced scattering and absorption signals and relatively uniform intensive properties $\AA_{\mathrm{sca}}^{405}$ and $\omega_{405}$ compared to periods shown in white, which are dominated by local inputs, and/or precipitation events where $\beta_{\text {abs }}$ and $\beta_{\text {sca }}$ are low and the intensive optical properties are highly variable. We identify aerosol pollution episodes occurring on 3, 6-8, 13-23, 27-31 August, and 3-13, 1620, 21-25, and 27-29 September (hence referred to as episodes 1-8) at Gosan stemming from transport of polluted Asian air masses (further evidenced by back trajectories). Over the transport episodes in CAPMEX, the mean $\beta_{\mathrm{abs}}$ at $405 \mathrm{~nm}$ during Asian transport episodes varies between 11 and $17 \mathrm{Mm}^{-1}$ while $\beta_{\text {sca }}$ varies between 42 and $411 \mathrm{Mm}^{-1}$. At $532 \mathrm{~nm}$, the mean $\beta_{\text {abs }}$ varies between 4 and $9 \mathrm{Mm}^{-1}$ while mean $\beta_{\text {sca }}$ varies between 23 and $280 \mathrm{Mm}^{-1}$ and at $781 \mathrm{~nm}$, mean $\beta_{\text {abs }}$ varies between 3 and $5 \mathrm{Mm}^{-1}$ while the mean $\beta_{\text {sca }}$ varies between 17 and $188 \mathrm{Mm}^{-1}$.
We observe the Ångström exponent of absorption $\left(\AA_{\text {abs }}(405 / 781)\right)$ is nearly constant (mean values $\sim 2.0$ ) for all transport episodes, indicating significant influence of absorbing organic material in each episode. To further diagnose the absorbing organic component, we use the Ångström exponent of absorption $\left(\AA_{\text {abs }}(405 / 532)\right)$, where the wavelength dependence is strongly influenced by organic content and we expect to see strong increases in the wavelength dependence at short wavelengths corresponding to absorption by organic material. The Ångström exponents over both wavelength ranges are included with the optical properties in Table 1. All $\AA_{\text {abs }}(405 / 532)$ are 2.9 or greater with the largest being 3.8 occurring during episode 8 , indicating the optical properties in episode 8 are possibly influenced by absorption enhancement at shorter wavelength due to OC.

\subsection{Chemical composition}

Independent mass and chemical information was assembled from simultaneous analysis of aerosol collected on quartz filters from 24-h periods during most of the campaign. The measured $\mathrm{PM}_{2.5}$ total mass temporal profile (in $\mu \mathrm{g} \mathrm{m}^{-3}$ ) included in Fig. 1 agrees very well with the $\beta_{\text {sca }}$ profile, independently separating Asian transport from local input periods. Also shown in Fig. 1 is the temporal profile of sulfate $\left(\mathrm{SO}_{4}^{2-}\right)$, ammonium $\left(\mathrm{NH}_{4}^{+}\right), \mathrm{OC}$, and $\mathrm{EC}$ as well the temporal profile of the $\mathrm{OC} / \mathrm{SO}_{4}^{2-}$ ratio. Sulfate and ammonium concentrations track the scattering observations while 
Table 1. Aerosol absorption and scattering coefficients at $405 \mathrm{~nm}, \omega_{405}, \AA_{\mathrm{sca}}^{405}$, Ångstrom exponents of absorption, with $1 \sigma$ standard deviations in parenthesis observed for pollution episodes and background periods during the 2008 CAPMEX field campaign. The background data is taken during the CAPMEX deployment when the Gosan Observatory was not experiencing one of the eight aerosol episodes. The statistics for the optical data are taken from 10 min averaged signal from the PASS-3.

\begin{tabular}{llcccccc}
\hline Episode & Dates & $\beta_{\text {abs }}$ & $\beta_{\text {sca }}$ & $\omega_{405}$ & $\AA_{\text {sca }}^{405}$ & $\AA_{\text {abs }}(405 / 781)$ & $\AA_{\text {abs }}(405 / 532)$ \\
\hline 1 & 3 Aug & $10.8(2.8)$ & $411.2(187.9)$ & $0.95(0.09)$ & $1.2(0.1)$ & $2.2(0.6)$ & $4.0(3.6)$ \\
2 & 6-7 Aug & $16.6(5.7)$ & $187.7(76.8)$ & $0.91(0.03)$ & $1.5(0.1)$ & $1.8(0.4)$ & $2.6(1.8)$ \\
3 & 13-23 Aug & $11.0(6.3)$ & $174.8(114.5)$ & $0.93(0.05)$ & $1.5(0.4)$ & $2.1(1.2)$ & $2.9(3.5)$ \\
4 & 27-31 Aug & $11.5(5.7)$ & $100.4(35.8)$ & $0.90(0.04)$ & $1.7(0.5)$ & $2.1(0.8)$ & $3.3(3.6)$ \\
5 & 3-12 Sep & $11.4(6.0)$ & $103.8(33.1)$ & $0.90(0.04)$ & $1.6(0.4)$ & $2.1(0.8)$ & $3.6(3.6)$ \\
6 & 16-20 Sep & $12.6(6.3)$ & $165.7(100.6)$ & $0.93(0.05)$ & $1.5(0.5)$ & $2.0(1.0)$ & $3.0(3.3)$ \\
7 & 21-25 Sep & $12.5(6.7)$ & $149.6(75.9)$ & $0.91(0.04)$ & $1.3(0.4)$ & $1.9(1.0)$ & $2.8(3.4)$ \\
8 & 27-29 Sep & $10.6(4.6)$ & $41.4(16.1)$ & $0.79(0.06)$ & $1.5(0.9)$ & $2.1(0.3)$ & $3.8(3.4)$ \\
Bkg. & & $5.5 \pm 3.6$ & $34.6 \pm 21.0$ & $0.84(0.11)$ & $1.49(1.3)$ & $2.88(1.7)$ & $3.13(5.3)$ \\
\hline
\end{tabular}

EC (and OC) measurements track the absorption measurements indicating independent, consistent, and robust plume identifications. We focus our discussion on $\mathrm{OC}_{2} \mathrm{SO}_{4}^{2-}$ and $\mathrm{NO}_{3}^{-} / \mathrm{SO}_{4}^{2-}$ ratios as metrics for aerosol composition since they vary significantly due to changes in source regions and the transport trajectory of the plumes (see Table 2).

The individual pollutants are enriched during transport episodes, though by varying amounts. The $\mathrm{SO}_{4}^{2-}$ mass (from the $\mathrm{PM}_{2.5}$ fraction) changed the most, episodic mean levels varied between 2.8 and $12.3 \mu \mathrm{g} \mathrm{m}^{-3}$, while there was less variation in $\mathrm{OC}\left(1.1-1.9 \mu \mathrm{g} \mathrm{m}^{-3}\right)$ and $\mathrm{NO}_{3}^{-}\left(0.7-1.9 \mu \mathrm{g} \mathrm{m}^{-3}\right)$ in transport episodes. Episode 3 has the largest sulfate mass $\left(12.3 \mu \mathrm{g} \mathrm{m}^{-3}\right)$ and the lowest $\mathrm{OC} / \mathrm{SO}_{4}^{2-}$ and $\mathrm{NO}_{3}^{-} / \mathrm{SO}_{4}^{2-} \mathrm{ra}-$ tios. This is consistent with back trajectories originating, at early times, 13-16 August, from the South China Sea and at late times, 17-23 August, northeast of Jeju and becoming enriched in sulfate pollution from southeastern China, an area influenced by a large number of power plants. The sulfate mass is comparable to a similar episode reported by Topping et al. ( $14.48 \mu \mathrm{g} \mathrm{m}^{-3}$ averaged over a 4 day episode originating in mainland China and passing through the southeastern part of China on its way to Jeju). Episode 8 exhibits the lowest sulfate mass $\left(2.8 \mu \mathrm{g} \mathrm{m}^{-3}\right)$ and highest $\mathrm{OC} / \mathrm{SO}_{4}^{2-}$ and $\mathrm{NO}_{3}^{-} / \mathrm{SO}_{4}^{2-}$ ratios of any episode in the deployment. The back trajectories originate in Siberia, where approximately 75 forest fires burned between 24 and 30 September 2008 (FIRMS, 2009). We expect the fire-impacted air mass to be rich in organics, and to entrain nitrogen-rich urban pollution and a modest amount of sulfate as the plume traverses northeastern China, an area with a lower number of power plants. In both the ACE-Asia (Topping et al., 2004) and CAPMEX results presented here, the $\mathrm{OC} / \mathrm{SO}_{4}^{2-}$ and $\mathrm{NO}_{3}^{-} / \mathrm{SO}_{4}^{2-}$ ratios are also lowest for air masses originating east of Beijing and traveling through southeastern China along their path to Jeju and highest for air masses originating in Siberia and north- east China. Episodes 4-6 are intermediate in sulfate mass as well as $\mathrm{OC} / \mathrm{SO}_{4}^{2-}$ and $\mathrm{NO}_{3}^{-} / \mathrm{SO}_{4}^{2-}$ ratios, and followed circuitous trajectories through the Sea of Japan, traversing over Japan and Korea, as well as remote continental Asian locations (see Table 2). In the next section our analysis will show that enhancements in particle organic carbon and nitrate relative to sulfate lead to increased light absorption at short wavelengths, underscoring the importance of treating such chemical effects on optical properties explicitly in climate and chemistry models.

\subsection{Optical property and chemical composition relationships}

We show the relationships between mean chemical composition $\left(\mathrm{OC} / \mathrm{SO}_{4}^{2-}\right.$ and $\left.\mathrm{NO}_{3}^{-} / \mathrm{SO}_{4}^{2-}\right)$ and the intensive optical properties $\omega_{405}$ and $\AA_{\text {abs }}(405 / 532)$ for episodes 3-8 in Fig. 2. These empirical correlations provide important clues to how chemical composition affects optical properties. The measured $\omega_{405}$ correlates inversely with the mean $\mathrm{OC}_{2} \mathrm{SO}_{4}^{2-}$ and $\mathrm{NO}_{3}^{-} / \mathrm{SO}_{4}^{2-}$ ratios, for carbonaceous aerosol originating from a range of source regions. Episode 8 has the lowest $\omega_{405}$ and highest $\mathrm{OC} / \mathrm{SO}_{4}^{2-}$ and $\mathrm{NO}_{3}^{-} / \mathrm{SO}_{4}^{2-}$ ratios; episode $3 \mathrm{ex}-$ hibits the highest $\omega_{405}$ and lowest $\mathrm{OC} / \mathrm{SO}_{4}^{2-}$ and $\mathrm{NO}_{3}^{-} / \mathrm{SO}_{4}^{2-}$ ratios. A variety of mechanisms, chemical and morphological, that could be responsible for the observed correlations are discussed and analyzed below. Nitrate rich plumes originate from $\mathrm{NO}_{\mathrm{x}}$ source regions where subsequent heterogeneous processing can enrich particle phase nitrate. If organics are present in the plumes, there is potential to form organic nitrates in the particle phase. Organic nitrates are known to absorb light at short wavelengths and are likely processed to the particle phase during LRT of pollution plumes rich in organics and nitrogen species such as episode 8 (Jacobson, 1998, 1999). Secondary acid-catalyzed reactions 
Table 2. Mass data $\left(\mu \mathrm{g} \mathrm{m}^{-3}\right.$ ) for Asian pollution transport episodes observed during CAPMEX. The uncertainty represents one standard deviation of the mean of the daily mass or ratio determined for each day in the episode. The last two columns are composition ratios and are unitless.

\begin{tabular}{lccccccc}
\hline Episode & $\mathrm{OC}$ & $\mathrm{EC}$ & $\mathrm{PM}_{2.5}$ & $\mathrm{NO}_{3}^{-}$ & $\mathrm{SO}_{4}^{2-}$ & $\mathrm{OC}_{\mathrm{SO}}^{2-}$ & $\mathrm{NO}_{3}^{-} / \mathrm{SO}_{4}^{2-}$ \\
\hline 1 & & & & & & & \\
2 & & & & & & \\
3 & $1.1 \pm 0.5$ & $0.1 \pm 0.1$ & $48.0 \pm 26.6$ & $0.74 \pm 0.4$ & $12.3 \pm 9.0$ & $0.12 \pm 0.1$ & $0.11 \pm 0.10$ \\
4 & $1.6 \pm 0.7$ & $0.2 \pm 0.1$ & $28.5 \pm 4.6$ & $1.1 \pm 0.3$ & $5.4 \pm 0.9$ & $0.31 \pm 0.1$ & $0.20 \pm 0.10$ \\
5 & $1.7 \pm 0.4$ & $0.2 \pm 0.1$ & $31.0 \pm 10.0$ & $1.2 \pm 0.3$ & $5.6 \pm 2.0$ & $0.32 \pm 0.1$ & $0.23 \pm 0.10$ \\
6 & $1.9 \pm 1.3$ & $0.3 \pm 0.2$ & $33.3 \pm 22.3$ & $1.4 \pm 0.9$ & $5.0 \pm 3.0$ & $0.36 \pm 0.1$ & $0.26 \pm 0.10$ \\
7 & $1.3 \pm 0.5$ & $0.2 \pm 0.1$ & $53.8 \pm 16.0$ & $1.3 \pm 0.2$ & $8.6 \pm 6.6$ & $0.15 \pm 0.1$ & $0.13 \pm 0.10$ \\
8 & $1.5 \pm 0.4$ & $0.2 \pm 0.1$ & $21.5 \pm 4.0$ & $1.9 \pm 0.9$ & $2.8 \pm 0.2$ & $0.56 \pm 0.1$ & $0.69 \pm 0.30$ \\
\hline
\end{tabular}

have also been shown by several groups to produce light absorbing organic material in aerosols (De Haan et al., 2009; Noziere et al., 2007; Shapiro et al., 2009; Bones et al., 2010). To assess the role of acid-catalyzed secondary reactions, we estimate the acidity of particles by calculating the ratio of measured molar concentration of major cations $\left[\mathrm{NH}_{4}^{+} / 18 \text { and } \mathrm{Na}^{+} / 23\right]_{\text {meas }}$ to the molar concentration of anions needed to neutralize $\left[\mathrm{NH}_{4}^{+}+\mathrm{Na}^{+}\right]_{\text {meas }}$, taken as the sum of the molar concentration of the major anionic species $\left[\mathrm{NH}_{4}^{+}\right.$ and $\left.\mathrm{Na}^{+}\right]_{\text {pred }}=\left[2 \times \mathrm{SO}_{4}^{2-} / 96+\mathrm{NO}_{3}^{-} / 62+\mathrm{Cl}^{-} / 35.5\right]$ (Zhang et al., 2005;Zhang et al., 2007). We include $\mathrm{Na}^{+}$due to the influence of sea-salt throughout the campaign. Dissolved organic acids may make a minor contribution to the charge balance but were not measured and are not considered here. When $\left[\mathrm{NH}_{4}^{+}+\mathrm{Na}^{+}\right]_{\text {meas }} /\left[\mathrm{NH}_{4}^{+}+\mathrm{Na}^{+}\right]_{\text {pred }} \approx 1.0$, the particles can be considered neutralized in the bulk and when the ratio is $<0.75$ the particles are acidic. For the particles in CAPMEX we calculate $\left[\mathrm{NH}_{4}^{+}+\mathrm{Na}^{+}\right]_{\text {meas }}=1.13 \pm 0.06$ $\left[\mathrm{NH}_{4}^{+}+\mathrm{Na}^{+}\right]_{\text {pred }}-0.00006 \pm 0.0109$, indicating the particles are not acidic in the bulk and does not support the hypothesis that light-absorbing material arose from acid-catalyzed reactions. However, particle nitration reactions may have a substantial effect on aerosol light absorption, especially under the transport conditions encountered here.

The changes in mass of $\mathrm{OC}$ and $\mathrm{NO}_{3}^{-}$are relatively small across the transport episodes, what changes significantly is the relative $\mathrm{SO}_{4}^{2-}$ percent composition $(86 \%$ in episode 3 , $44 \%$ in episode 8 , see Table 2 ). The changes in composition, size distribution, and mixing state influence the optical properties in pollution transport episodes observed during of CAPMEX. The decrease in $\omega_{405}$ could be attributed to reduction in particle size (which is observed directly and discussed in Sect. 3.4), thereby decreasing $\beta_{\text {sca }}$, or to changes in particle composition. To separate these effects, both $\AA_{\text {sca }}^{405}$ and $\AA_{\text {abs }}(405 / 532)$ are plotted as functions of composition ( $\left.\mathrm{OC}_{\mathrm{SO}}^{2-}\right)$ and included in Fig. 2. The increase in $\AA_{\text {abs }}$ (405/532) observed with increasing OC fraction demonstrates that enhanced short wavelength ab- sorption possibly associated with aerosol organic material plays a major role in the reduction of $\omega_{405}$. Furthermore, a similar strong positive trend exists (though not shown in Fig. 2) for $\AA_{\mathrm{abs}}(405 / 532) \mathrm{vs}$. $\mathrm{NO}_{3}^{-} / \mathrm{SO}_{4}^{2-}$ ratios during transport episodes in CAPMEX. Large poly-aromatic hydrocarbons and nitrated PAH molecules exhibit electronic absorption bands in the visible and could potentially be significant in this case as products of heterogeneous atmospheric processing (Ruiz-Morales and Mullins, 2007). In contrast, we find that $\AA_{\text {sca }}^{405}$ increases slightly with increasing $\mathrm{OC}_{\mathrm{SO}} \mathrm{SO}_{4}^{2-}$ ratios, showing the smaller particles more frequently occurred during the intermediate and high $\mathrm{OC} / \mathrm{SO}_{4}^{2-}$ events, a fact verified by the measurements of size distribution (Sect. 3.5). This is consistent with aged, mixed OC, sulfate, and nitrate aerosols exhibiting a propensity to absorb more light in the blue causing reduction of $\omega_{405}$.

\subsection{Brown carbon mass absorption cross section $\left(\mathrm{MAC}_{\mathrm{BrC}}\right)$ and coating effects on elemental carbon MAC (MAC EC}

We use the chemical composition and $\beta_{\mathrm{abs}}(\lambda)$ data to separate brown carbon, elemental carbon, and coating (morphological) contributions to total aerosol mass absorption cross sections using an empirical model: $\left(\mathrm{MAC}_{\text {total }}=\mathrm{MAC}_{\mathrm{EC}}+\mathrm{MAC}_{\mathrm{BrC}}\right)$. We have calculated the episodic $\mathrm{MAC}_{\text {total }}$ by dividing the measured absorption by the sum of measured $\mathrm{OC}$ and $\mathrm{EC}$ mass for each $\mathrm{OC} / \mathrm{SO}_{4}^{2-}$ episode $\quad\left[\mathrm{MAC}_{\text {total }}(\lambda)=\beta_{\mathrm{abs}}^{\text {meas }}(\lambda) /\left(\mathrm{EC}_{\text {mass }}+\mathrm{OC}_{\text {mass }}\right)\right]$. To estimate absorption by "uncoated" soot, we use published MAC values $\left(10.6 \pm 0.6 \mathrm{~m}^{2} \mathrm{~g}^{-1}\right.$ at $405 \mathrm{~nm}$, $7.32 \pm 0.5 \mathrm{~m}^{2} \mathrm{~g}^{-1}$ at $532 \mathrm{~nm}, \quad 4.24 \pm 0.2 \mathrm{~m}^{2} \mathrm{~g}^{-1}$ at $781 \mathrm{~nm}$ ) for denuded soot collected in a recent laboratory study (Cross et al., 2010). We then multiply our observed $\mathrm{EC}_{\text {mass }}$ by the aforementioned MAC to estimate the light absorption from uncoated elemental carbon $\left(\beta_{\mathrm{abs}}^{\text {est }}=\mathrm{MAC}_{\text {denuded soot }} \times \mathrm{EC}_{\text {mass }}^{\text {meas }}\right)$ at each PASS-3 wavelength. We then postulate OC absorption is negligible at $781 \mathrm{~nm}$ and dominated by black carbon and empirically 


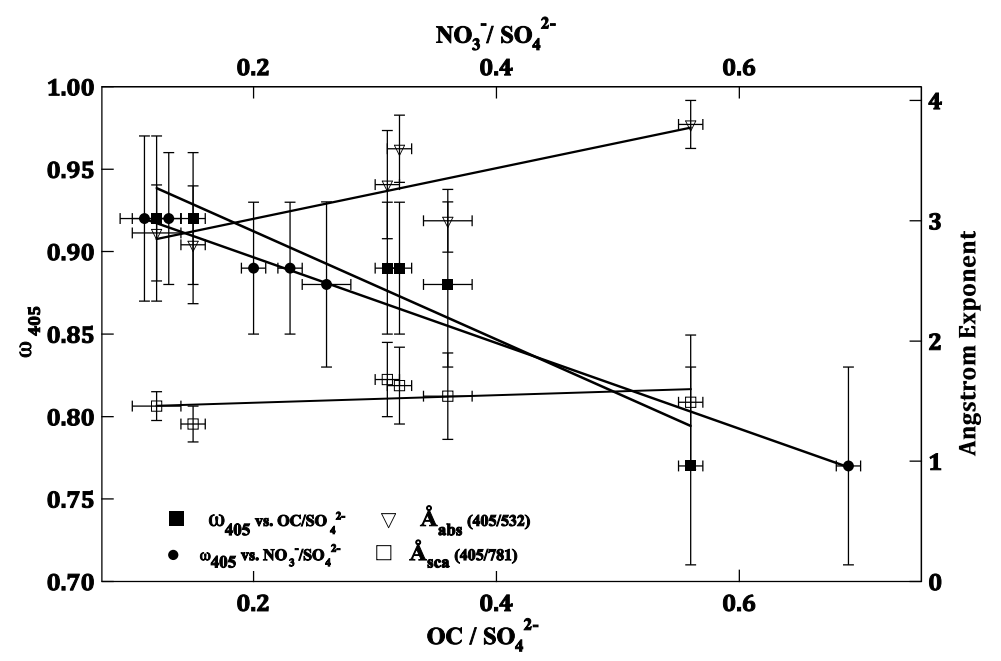

Fig. 2. Single scatter albedo at $405 \mathrm{~nm}$ plotted against $\mathrm{OC}_{\mathrm{SO}_{4}^{2-}}$ and against $\mathrm{NO}_{3}^{-} / \mathrm{SO}_{4}^{2-}, \AA_{\mathrm{abs}}(405 / 532)$ plotted vs. OC/SO $\mathrm{S}_{4}^{2-}$, and $\AA_{\mathrm{sca}}^{405}$ vs. $\mathrm{OC} / \mathrm{SO}_{4}^{2-}$ for episodes 3-8 of CAPMEX. The highest $\omega_{405}$ occurred for the lowest $\mathrm{OC} / \mathrm{CO}_{4}^{2-}$ ratio $(0.93$ and 0.12 ; episode 3$)$ and the lowest $\omega_{405}$ occurred for the highest $\mathrm{OC}_{\mathrm{SO}}{ }_{4}^{2-}$ ratio $(0.79$ and 0.56 ; episode 8$)$.

determine a factor that best matches $\beta_{\mathrm{abs}}^{\text {est }}$ to our measured $\beta_{\text {abs }}(781 \mathrm{~nm}) ;\left(\beta_{\mathrm{abs}}^{\text {est }}=f \times \beta_{\mathrm{abs}}^{\text {meas }}\right)$. We interpret $f$ as the absorption enhancement factor for the coating and find that this ranges from 3-6 (at $781 \mathrm{~nm}$ ) for the transport episodes in CAPMEX. This is attributed to the net absorption enhancement by clear and/or absorbing coatings on elemental carbon aerosol cores. Our values are much higher than the enhancement reported in limited observational studies (Cross et al., 2010) (Schwarz et al., 2008). We hypothesize that large enhancements observed in CAPMEX can result from increased coating thickness during aerosol transport than in laboratory studies (Cross et al., 2010) and also the mixed carbonaceous aerosol may contain material that absorbs in the red (Gyawali et al., 2009; Garland et al., 2008). Thick coating on mixed carbonaceous aerosol are pervasive in polluted environments, as reported in the Mexico City outflow where morphological analysis demonstrated that black carbon were coated $55 \%$ of the time with a median volume fraction of 15\% (Adachi and Buseck, 2008). Additionally, we are able to determine percent contributions of EC and $\mathrm{EC}$ coating to the overall $\beta_{\mathrm{abs}}^{\text {meas }}$ at each wavelength using $\left[\beta_{\mathrm{abs}}^{\text {est }}(\lambda) / \beta_{\mathrm{abs}}^{\text {meas }}(\lambda)\right]$. We find elemental carbon absorption and the coating effect accounted for $73 \%$ of $\beta_{\text {abs }}(405 \mathrm{~nm})$ in episode 7 and $99 \%$ of $\beta_{\text {abs }}(532 \mathrm{~nm})$ in episodes 5 and 8 . The smallest coating effect was observed during episode 8 (33\% at $405 \mathrm{~nm}$ ).

Finally, we are able to estimate $\mathrm{MAC}_{\mathrm{BrC}}$ for carbonaceous aerosols from our CAPMEX data. The difference between our $\beta_{\text {abs }}^{\text {meas }}(405 \mathrm{~nm})$ and $\beta_{\text {abs }}^{\text {meas }}(532 \mathrm{~nm})$ compared with $\beta_{\text {abs }}^{\text {est }}$ (at 405 and $532 \mathrm{~nm}$ ) is attributed to brown carbon absorption (additional absorption than has been accounted for by the coating of elemental carbon cores). We determine $\mathrm{MAC}_{\mathrm{BrC}}$ by $\left[\left(\beta_{\mathrm{abs}}^{\text {meas }}-\beta_{\mathrm{abs}}^{\text {est }}\right) / \mathrm{OC}_{\mathrm{mass}}\right]$. We infer $\mathrm{MAC}_{\mathrm{BrC}}$ ranging be- tween $2.1 \pm 0.1$ and $3.4 \pm 0.1 \mathrm{~m}^{2} \mathrm{~g}^{-1}$ at $405 \mathrm{~nm}$ and between $0 \pm 0.1$ and $1.0 \pm 0.1 \mathrm{~m}^{2} \mathrm{~g}^{-1}$ at $532 \mathrm{~nm}$ and that brown carbon accounts for up to $50 \%$ of $\beta_{\mathrm{abs}}^{\text {meas }}(405 \mathrm{~nm})$ in episode 8 and up to $20 \%$ of $\beta_{\mathrm{abs}}^{\text {meas }}(532 \mathrm{~nm})$ in episode 2. Table 3 exhibits the $\mathrm{MAC}_{\mathrm{BrC}}$ and absorption fractions for each episode. Similar MACs for OC have been reported (Favez et al., 2009) and similar EC and OC contributions to total aerosol absorption have been observed for ambient mixed carbonaceous aerosol (Barnard et al., 2008; Clarke et al., 2004). Our analysis elucidates how light absorption is enhanced by brown carbon directly and indirectly by coatings on elemental carbon cores for the CAPMEX episodes. We find that coated EC makes a considerable contribution at 405 and $532 \mathrm{~nm}$ for all episodes except for the fire-impacted episode 8 . Our MAC results for brown and coated elemental carbon should be valuable for constraining $\mathrm{MAC}_{\mathrm{EC}}$ and $\mathrm{MAC}_{\mathrm{BrC}}$ for carbonaceous aerosol and quantitatively determining their impacts on radiative forcing and photochemistry.

\subsection{Wavelength dependent refractive indices from size and optical properties}

Particle number size distributions were measured during CAPMEX using both SMPS and APS particle sizers. The SMPS and APS particle diameters are merged into a distribution covering 10.4 to $19800 \mathrm{~nm}$. The APS particle aerodynamic diameters were converted to actual diameters using a procedure outlined by (Hand and Kreidenweis, 2002). A reference particle density of $1.6 \mathrm{~g} \mathrm{~cm}^{-3}$ is assumed throughout. We have separated the number size distributions into three groups according to the $\mathrm{OC} / \mathrm{SO}_{4}^{2-}$ ratio, the same as for the optical property correlations: high (mean distribution for episode 8), intermediate (mean distribution for episodes 
Table 3. Mass Absorption Cross Sections $\left(\mathrm{MAC}_{\text {total }}\right)$, brown carbon $\mathrm{MAC}\left(\mathrm{MAC}_{\mathrm{BrC}}\right)$, enhancement factor $(f)$, and percent contribution to total absorption $\left[\beta_{\mathrm{abs}}(405 \mathrm{~nm})\right.$ and $\left.\beta_{\mathrm{abs}}(532 \mathrm{~nm})\right]$ for Asian transport episodes observed during CAPMEX.

\begin{tabular}{|c|c|c|c|c|c|c|c|c|c|c|c|c|c|}
\hline \multirow[t]{2}{*}{ Episode } & \multicolumn{3}{|c|}{ MAC $_{\text {total }}$} & \multicolumn{3}{|c|}{$\mathrm{MAC}_{\mathrm{BrC}}$} & \multirow[t]{2}{*}{$f$} & \multirow[t]{2}{*}{ EC } & \multirow{2}{*}{$\frac{\mathrm{EC}+\mathrm{coat}}{405 \mathrm{~nm}}$} & \multirow[t]{2}{*}{ OC } & \multirow[t]{2}{*}{$\mathrm{EC}$} & \multirow{2}{*}{$\frac{E C+\text { coat }}{532 \mathrm{~nm}}$} & \multirow[t]{2}{*}{$\mathrm{OC}$} \\
\hline & $405 \mathrm{~nm}$ & $532 \mathrm{~nm}$ & $781 \mathrm{~nm}$ & $405 \mathrm{~nm}$ & $532 \mathrm{~nm}$ & $781 \mathrm{~nm}$ & & & & & & & \\
\hline 3 & $9.0 \pm 0.1$ & $4.8 \pm 0.1$ & $2.6 \pm 0.1$ & $3.4 \pm 0.1$ & $1.0 \pm 0.1$ & $0.4 \pm 0.1$ & 6.0 & 0.10 & 0.65 & 0.34 & 0.17 & 0.82 & 0.17 \\
\hline 5 & $6.3 \pm 0.1$ & $2.6 \pm 0.1$ & $1.7 \pm 0.1$ & $2.5 \pm 0.1$ & $0.0 \pm 0.1$ & $0.2 \pm 0.1$ & 4.3 & 0.16 & 0.66 & 0.34 & 0.23 & 0.99 & 0.01 \\
\hline 6 & $5.0 \pm 0.1$ & $2.2 \pm 0.1$ & $1.2 \pm 0.1$ & $2.1 \pm 0.1$ & $0.2 \pm 0.1$ & $0.0 \pm 0.1$ & 3.0 & 0.22 & 0.67 & 0.32 & 0.31 & 0.93 & 0.07 \\
\hline 7 & $8.5 \pm 0.1$ & $4.3 \pm 0.1$ & $2.6 \pm 0.1$ & $2.8 \pm 0.1$ & $0.4 \pm 0.1$ & $0.3 \pm 0.1$ & 4.3 & 0.17 & 0.73 & 0.27 & 0.22 & 0.93 & 0.07 \\
\hline
\end{tabular}

$4,5,6$ ) and low (mean distribution for episodes 3,7 ). The merged results for the high, intermediate, and low $\mathrm{OC}_{\mathrm{SO}} \mathrm{S}_{4}^{2-}$ episodes are shown in Fig. 3. We find mean particle diameters calculated from each merged size distribution for the $\mathrm{OC} / \mathrm{SO}_{4}^{2-}$ ratio groups are $72.4 \mathrm{~nm}, 92.5 \mathrm{~nm}$, and $124.5 \mathrm{~nm}$ for the high, intermediate, and low $\mathrm{OC} / \mathrm{SO}_{4}^{2-}$ ratios, respectively. A shift to smaller size at higher $\mathrm{OC} / \mathrm{SO}_{4}^{2-}$ ratios is consistent with expectations based on back-trajectories and distinct chemical compositions of the sources. The mean particle diameters are also consistent with the slight rise in $\AA_{\text {sca }}(405 / 781)$ with increasing OC/SO ${ }_{4}^{2-}$ as shown in Fig. 2. The CPC total count is used to adjust the total concentration count and account for particle losses within the SMPS. The SMPS plus APS size distributions, together with the CPC total count, are used as constraints to determine effective refractive indexes inferred from fitting the mean aerosol optical properties measured by the PASS-3. The ratio defined as $A_{\mathrm{CPC}}=\mathrm{CPC} / \mathrm{SMPS}$ is on average 4.2 over the data range available during the entire campaign; however, this value is highly variable for the different episodes; therefore to further constrain its value, we adjusted $A_{\mathrm{CPC}}$ by constraining the fitted real part of the index of refraction for the aerosol measured during the low $\mathrm{OC} / \mathrm{SO}_{4}^{2-}$ episodes. For this case we assumed tabulated values for the real part of the index of refraction for sulfate and for EC and OC in the green, and derived a volume-averaged value of $n=1.435$ (d'Almeida et al., 1991; Bond and Bergstrom, 2006). The reason for using the low $\mathrm{OC} / \mathrm{SO}_{4}^{2-}$ episode as a constraint is that the $\mathrm{EC}$ and $\mathrm{OC}$ component contribute minimally to the real index of refraction at $532 \mathrm{~nm}$ and therefore the exact value of their refractive indices is not critical. A particle count adjustment factor $A_{\mathrm{CPC}}=3.78$ was found by forcing the fitting to $n=1.435$ and the $A_{\mathrm{CPC}}$ was used for the rest of the fitting analysis. The fitting is done using a homogeneous sphere Mie theory code to match the optical property observations (absorption and scattering at three wavelengths) for the high, medium, and low $\mathrm{OC} / \mathrm{SO}_{4}^{2-}$ cases as discussed next.

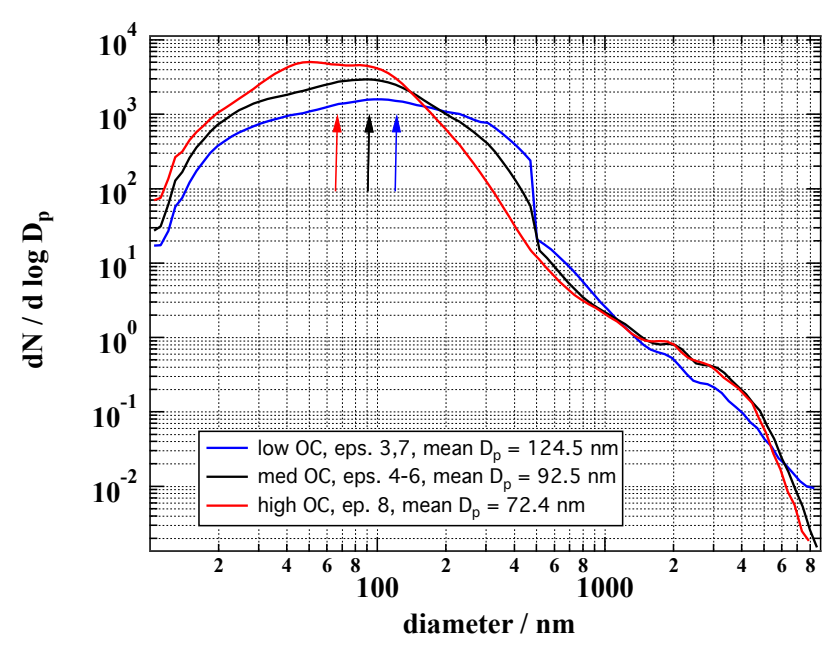

Fig. 3. Particle number size distribution measured with SMPS and APS systems during CAPMEX. The mean particle diameters calculated from the number distributions are $72.4 \mathrm{~nm}, 92.5 \mathrm{~nm}$, and $124.5 \mathrm{~nm}$ for the high, intermediate, and low $\mathrm{OC}_{\mathrm{SO}} \mathrm{S}_{4}^{2-}$ episodes and their locations in the number distribution are shown by the color-coded arrows.

To retrieve the complex refractive indices $(n-i k)$ for all cases for different wavelengths, we follow the procedure described next. Using the scaled observed number size distributions $\left(A_{\mathrm{CPC}} \mathrm{d} N / \mathrm{d} \log D p\right.$ ) for particles smaller than $2000 \mathrm{~nm}$, we vary the real and imaginary parts of the refractive index to match the mean values of the observed $\beta_{\mathrm{abs}}(\lambda)$ and $\beta_{\text {sca }}(\lambda)$ independently for each PASS- 3 wavelength. We then calculate a weighted average residual between the measured and the calculated $\beta_{\text {abs }}(\lambda)$ and $\beta_{\text {sca }}(\lambda)$ and take the average and the standard deviation of the indices of refraction that result in a discrepancy between the predicted and measured data that is below $5 \%$. The $5 \%$ threshold was chosen as a conservative representation of the measurement uncertainty. This fitting process is repeated for each of the $\mathrm{OC} / \mathrm{SO}_{4}^{2-}$ cases to determine effective bulk imaginary indices of refraction for ambient mixed carbonaceous aerosol undergoing 
transport to Jeju. The complex refractive indices for each of the high, intermediate, and low $\mathrm{OC} / \mathrm{SO}_{4}^{2-}$ episode groups are separated into their real and imaginary parts and plotted against wavelength in Fig. 4. The error bars represent only the standard deviation of the mean of the real and imaginary parts of the refractive index and do not include other sources of uncertainties (e.g. uncertainties in particle concentration). The mean particle diameters and wavelength dependent complex refractive indices for the low, intermediate, and high $\mathrm{OC} / \mathrm{SO}_{4}^{2-}$ cases are listed in Table 4.

Enhanced absorption by organic and nitrate rich aerosol is evident in the observed increase of the imaginary part of the refractive index $(\delta k / \delta \lambda)$ and by the enhanced rate of increase with wavelength $(k / \lambda)$ at short wavelengths. The imaginary part of the refractive index $(k)$ is greater for larger $\mathrm{OC} / \mathrm{SO}_{4}^{2-}$ ratios at all wavelengths. A distinct, sharp increase in $k$ at short wavelength $(405 \mathrm{~nm})$ for the high $\mathrm{OC} / \mathrm{SO}_{4}^{2-}$ episode implies enhanced light absorption by $\mathrm{OC}$ in this forest-fire impacted plume (Chakrabarty et al., 2010). As the $\mathrm{OC} / \mathrm{SO}_{4}^{2-}$ ratio increases, $(\delta k / \delta \lambda)$ increases as well. The highest value at $405 \mathrm{~nm}$ for $k(0.029)$ is observed for the high $\mathrm{OC} / \mathrm{SO}_{4}^{2-}$ episode 8 . We hypothesize that the absorption enhancement at short wavelength is due to absorption by OC (e.g. large polyaromatics) or by $\mathrm{OC}$ processed in the presence of $\mathrm{NO}_{\mathrm{x}}$ to particle phase organic nitrates. We also note that there is short-wavelength enhancement in $k$ for each episode, showing the general absorption enhancement of OC, which is present in each composition ratio group. The largest enhancement for $k\left(200 \% ;\left(k_{405} \mathrm{~nm}\right) /\left(k_{781} \mathrm{~nm}\right)\right)$ is calculated for the high $\mathrm{OC} / \mathrm{SO}_{4}^{2-}$ episode, also corresponding to the lowest $\omega_{405}$ measured for any aerosol transport episode in the campaign. The enhancement is less for medium and low $\mathrm{OC} / \mathrm{SO}_{4}^{2-}$ and $\mathrm{NO}_{3}^{-} / \mathrm{SO}_{4}^{2-}$ ratios $(\sim 150 \%)$, which indicates that $\omega(\lambda)$ is determined by the amount of $\mathrm{OC}, \mathrm{NO}_{3}^{-}$and $\mathrm{SO}_{4}^{2-}$ in mixed carbonaceous aerosol, primarily at shorter wavelengths. Taken together, the in situ $\omega(\lambda)$, composition, and size distribution measurements, and the calculated complex refractive indices corroborate reports of enhanced short wave absorption in remote column radiance data for carbonaceous aerosol made in Mexico City (Barnard et al., 2008), for example. Additionally, the wavelength dependence of our complex refractive indices at 405,532 , and $781 \mathrm{~nm}$ determined from our direct and comprehensive in situ measurements of aged, complex mixed carbonaceous aerosol at Cheju over a 2 month period are consistent with analysis of a handful of quartz filter samples of much less aged urban pollution and smoke samples (from Weizmann Institute rooftop in Rehovot, Israel) at 390 and $532 \mathrm{~nm}$ reported by (Dinar et al., 2008), and the complex refractive index at $550 \mathrm{~nm}$ from a similar size-resolved optical property analysis of some fresh biomass smoke samples in the laboratory (Hungershoefer et al., 2008).

We compare the complex refractive indices derived above with independently measured $\mathrm{PM}_{2.5}$ total mass, $\mathrm{EC}_{\text {mass }}$, and
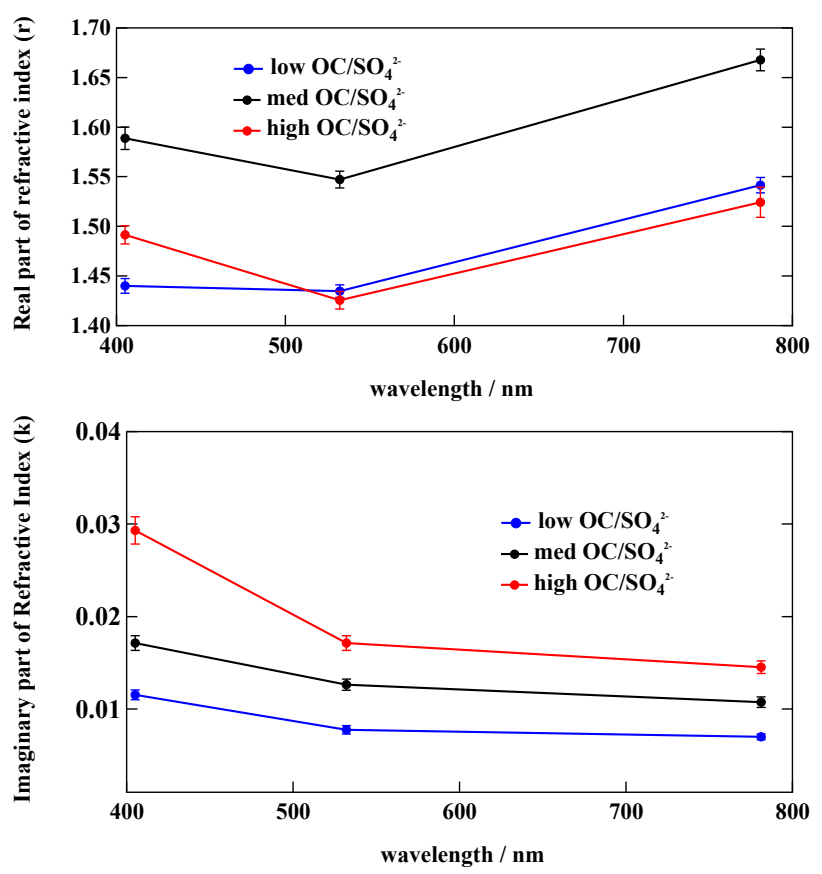

Fig. 4. Complex refractive index for calculated for low, medium, and high $\mathrm{OC} / \mathrm{SO}_{4}^{2-}$ episodes in CAPMEX. The color-coding is analogous to Fig. 3, the high $\mathrm{OC} / \mathrm{SO}_{4}^{2-}$ case is in blue, the intermediate $\mathrm{OC} / \mathrm{SO}_{4}^{2-}$ in black and the high $\mathrm{OC} / \mathrm{SO}_{4}^{2-}$ case in red.

$\mathrm{OC}_{\text {mass }}$ composition data for closure and to quantify the effects of mixing and processing. The mean EC and OC mass percentage of $\mathrm{PM}_{2.5}$ total mass are 0.3 and $2.8 \%$ for the low $\mathrm{OC} / \mathrm{SO}_{4}^{2-}$ case, 0.7 and $5.6 \%$ for the intermediate $\mathrm{OC} / \mathrm{SO}_{4}^{2-}$ case, and 0.7 and $7.8 \%$ for the high $\mathrm{OC} / \mathrm{SO}_{4}^{2-}$ case. Using our derived $\mathrm{k}$ values at $781 \mathrm{~nm}$, we can estimate the episodic coating factor $(f)$ by considering the ratio: $f=k_{781}^{\text {calc }} /((\mathrm{EC}$ $\mathrm{PM}_{2.5}$ mass $\left.\left.\% / 100\right) \times k_{781}^{\text {ref }}\right)$, where $k_{781}^{\text {ref }}=0.71$, the wavelength independent imaginary component of the refractive index of soot (Bond and Bergstrom, 2006). Estimation of $f$ in this fashion for the each of the $\mathrm{OC} / \mathrm{SO}_{4}^{2-}$ cases gives coating enhancement factors of 3.1, 2.0, and 2.7. These absorption enhancements at $781 \mathrm{~nm}$ are smaller (due to mass based approximate optical calculations) but are consistent with the mean coating enhancement factors 5.2, 3.6, and 3.2 calculated independently for the low, intermediate, and high $\mathrm{OC} / \mathrm{SO}_{4}^{2-}$ cases in Sect. 3.4. The largest enhancement is predicted for the low $\mathrm{OC} / \mathrm{SO}_{4}^{2-}$ case with either method and the higher $\mathrm{OC} / \mathrm{SO}_{4}^{2-}$ cases exhibit similar mean predicted absorption enhancements. Additionally, we are able to separate $k_{\mathrm{EC}}$ from $k_{\mathrm{BrC}}$ using $\left(k_{405}^{\text {calc }}-k_{781}^{\text {calc }}\right)$ and determine an effective $k_{\mathrm{BrC}}^{\prime}$ that matches the episodic OC $\mathrm{PM}_{2.5}$ mass percent from the filter analysis, i.e. OC mass percent $\%=\left[\left(k_{405}^{\text {calc }}-k_{781}^{\text {calc }}\right) / k_{\mathrm{BrC}}^{\prime}\right] \times 100$. The $k_{\mathrm{BrC}}^{\prime}$ term describes the imaginary component of the refractive index of the nonsoot material in the aerosol, likely a mixture of absorbing $\mathrm{OC}$ and nitrated-OC. Optimizing $k_{\mathrm{BrC}}^{\prime}$ for all three cases, 
Table 4. Mean particle diameters and complex refractive indices for the low, intermediate, and high $\mathrm{OC}_{\mathrm{SO}}^{2-} \mathrm{cases}_{4}$ in $\mathrm{CAPMEX}$. The complex refractive indices are calculated from an iterative procedure constrained by observed wavelength dependent optical properties, discussed in the text. The mean particle diameters are calculated from the merged particle number size distributions in each of the low, intermediate, and high $\mathrm{OC} / \mathrm{SO}_{4}^{2-}$ cases.

\begin{tabular}{|c|c|c|c|}
\hline Composition ratio & Mean particle diameter & Wavelength/nm & Complex refractive index \\
\hline \multirow[t]{3}{*}{ low $\mathrm{OC} / \mathrm{SO}_{4}^{2-}$} & $124.5 \mathrm{~nm}$ & 405 & $1.440 \pm 0.01-0.012 \pm 0.001 i$ \\
\hline & & 532 & $1.434 \pm 0.01-0.008 \pm 0.001 i$ \\
\hline & & 781 & $1.542 \pm 0.01-0.007 \pm 0.001 i$ \\
\hline \multirow[t]{3}{*}{ intermediate $\mathrm{OC} / \mathrm{SO}_{4}^{2-}$} & $94.5 \mathrm{~nm}$ & 405 & $1.590 \pm 0.01-0.017 \pm 0.001 i$ \\
\hline & & 532 & $1.547 \pm 0.01-0.013 \pm 0.001 i$ \\
\hline & & 781 & $1.668 \pm 0.01-0.011 \pm 0.001 i$ \\
\hline \multirow[t]{3}{*}{ high $\mathrm{OC} / \mathrm{SO}_{4}^{2-}$} & $72.5 \mathrm{~nm}$ & 405 & $1.492 \pm 0.01-0.029 \pm 0.001 i$ \\
\hline & & 532 & $1.426 \pm 0.01-0.017 \pm 0.001 i$ \\
\hline & & 781 & $1.524 \pm 0.02-0.015 \pm 0.001 i$ \\
\hline
\end{tabular}

we determine that $k_{\mathrm{BrC}}^{\prime}=0.17,0.11$, and 0.16 match the OC $\mathrm{PM}_{2.5}$ mass percent for the high, intermediate, and low $\mathrm{OC} / \mathrm{SO}_{4}^{2-}$ cases, respectively. Many poly-aromatics and nitrated PAH species have $k$ values between 0.1 and 1 near $400 \mathrm{~nm}$, see table 3 in Jacobson (1999), and their formation and entrainment in particles, especially during transport, can increase short wavelength absorption appreciably. We have closed the loop between the particle size distributions, chemical composition, and optical properties to show how the chemistry and morphology of mixed carbonaceous aerosol can significantly increase their ability to absorb sunlight, thereby forcing climate and altering local photochemistry.

\section{Conclusions and significance}

Transport of absorbing carbonaceous aerosols accounted for $76 \%$ of the observation time on Jeju, South Korea in August and September 2008. We sampled a range of polluted air masses with varying amounts of particle carbon, sulfate, organics, and nitrate. Direct photoacoustic measurements of intensive optical properties are empirically correlated with chemical composition observations. Episodes with high $\mathrm{OC} / \mathrm{SO}_{4}^{2-}$ and $\mathrm{NO}_{3}^{-} / \mathrm{SO}_{4}^{2-}$ ratios exhibit lower $\omega_{405}$, which is corroborated by the optical closure analysis. We close the loop between particle size, composition, and optical property data by using them to extract wavelength-dependent complex refractive indices over a range of $\mathrm{OC} / \mathrm{SO}_{4}^{2-}$ ratios. We predict the largest $k(0.029)$ at $405 \mathrm{~nm}$ for episode 8 , which has the highest $\mathrm{OC} / \mathrm{SO}_{4}^{2-}$ ratio, and the imaginary component is $2.4 \times$ greater than $k$ predicted at $405 \mathrm{~nm}$ for the low $\mathrm{OC} / \mathrm{SO}_{4}^{2-}$ case. We used the complex refractive indices to make similar quantitative conclusions about the coating absorption enhancement factor compared with an analysis based solely on chemical composition and optical properties. Also, we show that $\mathrm{MAC}_{\mathrm{BrC}}$ can represent a substantial part of the total MAC for carbonaceous aerosol. Overall, our findings underscore the manner in which OC can enhance light absorption by coating and mixing with EC and exhibits how absorbing and non-absorbing components of carbonaceous aerosol can moderate absorption across the visible spectrum.

A recent study shows that a small reduction in global mean aerosol single scatter albedo $(0.986$ to 0.970 at $550 \mathrm{~nm})$ from a higher absorbing carbonaceous fraction increases the net anthropogenic radiative forcing to $-0.3 \mathrm{Wm}^{-2}$ from $-0.5 \mathrm{Wm}^{-2}$ (Myhre, 2009). For a fire-impacted high $\mathrm{OC}_{2} \mathrm{SO}_{4}^{2-}$ episode in CAPMEX, we observed $\left[\omega_{405}=\right.$ $\left.0.79 \pm 0.05, \omega_{532}=0.84 \pm 0.10, \omega_{781}=0.83 \pm 0.11\right]$ compared with mean $\left[\omega_{405}=0.92 \pm 0.05, \omega_{532}=0.94 \pm 0.06\right.$, $\left.\omega_{781}=0.95 \pm 0.05\right]$ observed during two low $\mathrm{OC}_{\mathrm{SO}}^{2-}$ episodes. Chemical composition (both absorbing and nonabsorbing, organic and inorganic components) significantly affects aerosol optical properties particularly at shorter wavelengths, especially during transport. Furthermore, our empirical analysis also show that coatings and processing during transport may enhance light absorption by black carbon by factors of greater than 3 indicating that the published estimates of warming and heating rates derived from filter-based particle absorption measurements are likely too low and need re-examination for wavelength and composition dependence (Ramana et al., 2010). Our results underscore the need to explicitly parameterize aerosol composition effects on wavelength dependent optical properties in regional chemistry and climate models to asses their climate impacts, particularly in the Asian outflow, whose composition is changing due to energy growth and clean air policies. Our chemical-optical relations and derived wavelength dependent MACs for carbonaceous aerosols provide empirical parameterizations that enable such analysis by modelers. 
Acknowledgements. This work was funded by the United States Department of Energy ASR and ARM grants to M. K. Dubey (PI). We gratefully acknowledge V. Ramanathan and M. V. Ramana (UCSD) for critical discussions, logistical assistance, and organization of the CAPMEX campaign. The authors thank John Walker (DMT) for instrument installation and field operation. We also thank an anonymous reviewer for suggestions concerning measured size distributions that were quite helpful strengthening the manuscript. S.-C. Yoon and S.-W. Kim was supported by the BK21 program of the School of Earth and Environmental Sciences, Seoul National University, and by the Korea Meteorological Administration Research and Development Program under Grant RACS 2010-1009.

Edited by: H. Moosmüller

\section{References}

Adachi, K. and Buseck, P. R.: Internally mixed soot, sulfates, and organic matter in aerosol particles from Mexico City, Atmos. Chem. Phys., 8, 6469-6481, doi:10.5194/acp-8-6469-2008, 2008.

Andreae, M. O. and Gelencsér, A.: Black carbon or brown carbon? The nature of light-absorbing carbonaceous aerosols, Atmos. Chem. Phys., 6, 3131-3148, doi:10.5194/acp-6-3131-2006, 2006.

Barnard, J. C., Volkamer, R., and Kassianov, E. I.: Estimation of the mass absorption cross section of the organic carbon component of aerosols in the Mexico City Metropolitan Area, Atmos. Chem. Phys., 8, 6665-6679, doi:10.5194/acp-8-6665-2008, 2008.

Bond, T. C. and Bergstrom, R. W.: Light Absorption by Carbonaceous Particles: An Investigative Review, Aerosol Sci. Technol., 40, 27-67, 2006.

Bond, T. C., Habib, G., and Bergstrom, R. W.: Limitations in the enhancement of visible light absorption due to mixing state, J. Geophys. Res., 111, D20211, doi:20210.21029/22006JD007315, 2006.

Bones, D. L., Henricksen, D. K., Mang, S. A., Gonsior, M., Bateman, A. P., Nguyen, T. B., Cooper, W. J., and Nizkorodov, S. A.: Appearance of strong absorbers and fluorophores in limoneneO3 secondary organic aerosol due to NH4+-mediated chemical aging over long time scales, J. Geophys. Res., 115, D05203, doi:10.1029/2009jd012864, 2010.

Chakrabarty, R. K., Moosmller, H., Chen, L.-W. A., Lewis, K., Arnott, W. P., Mazzoleni, C., Dubey, M. K., Wold, C. E., Hao, W. M., and Kreidenweis, S. M.: Brown carbon in tar balls from smoldering biomass combustion, Atmos. Chem. Phys., 10, 6363-6370, doi:10.5194/acp-10-6363-2010, 2010.

Chen, L.-L., Carmichael, G. R., Hong, M.-S., Ueda, H., Shim, S., Song, C. H., Kim, Y. P., Arimoto, R., Prospero, J., Savoie, D., Murano, K., Park, J. K., Lee, H.-g., and Kang, C.: Influence of continental outflow events on the aerosol composition at Cheju Island, South Korea, J. Geophys. Res., 102, 28551-28574, 1997.

Chow, J. C., Watson, J. G., Doraiswamy, P., Chen, L.-W., Sodeman, D. A., Lowenthal, D. H., Park, K., Arnott, P. W., and Motallebi, N.: Aerosol light absorption, black carbon, and elemental carbon at the Fresno Supersite, California, Atmos. Res., 93, 874-887, 2009.
Clarke, A. D., Shinozuka, Y., Kapustin, V. N., Howell, S., Huebert, B., Doherty, S., Anderson, T., Covert, D., Anderson, J., Hua, X., Moore, K. G., II, McNaughton, C., Carmichael, G., and Weber, R.: Size distributions and mixtures of dust and black carbon aerosol in Asian outflow: Physiochemistry and optical properties, J. Geophys. Res., 109, D15S09, doi:10.1029/2003JD004378, 2004.

Cross, E. S., Onasch, T. B., Ahern, A., Wrobel, W., Slowik, J., Olfert, J., Lack, D., Massoli, P., Cappa, C., Schwarz, J., Spackman, R., Fahey, D., Sedlacek, A., Trimborn, A., Jayne, J., Freedman, A., Williams, L., Ng, N. L., Mazzoleni, C., Dubey, M., Brem, B., Kok, G., Subramanian, R., Freitag, S., Clarke, A., Thornhill, D., Marr, L., Kolb, C., Worsnop, D., and Davidovits, P.: Soot Prticle Studies - Instrument Inter-Comparison - Project Overview, Aerosol Sci. Technol., 44, 592-611, 2010.

d'Almeida, G., Koepke, P., and Shettle, E. P.: Atmospheric aerosols: global climatology and radiative characteristics, A. Deepak Publishing, Hampton, VA, 1991.

De Haan, D. O., Tolbert, M. A., and Jimenez, J. L.: Atmospheric condensed-phase reactions of glyoxal with methylamine, Geophys. Res. Lett., 36, L11819, doi:10.1029/2009g1037441, 2009.

Dinar, E., Abo Riziq, A., Spindler, C., Erlick, C., Kiss, G., and Rudich, Y.: The complex refractive indec of atmospheric and model humic-like substances (HULIS) retrieved by a cavity ringdown aerosol spectrometer, Faraday Discuss., 137, 279-295, 2008.

HYSPLIT (HYbrid Single-Particle Lanrangian Integrated Trejectory) Model access via NOAA ARL READY (http://wwww. arl.noaa.gov/ready/hysplit4.html), NOAA Air Resources Laboratory, 2003.

Dunlea, E. J., DeCarlo, P. F., Aiken, A. C., Kimmel, J. R., Peltier, R. E., Weber, R. J., Tomlinson, J., Collins, D. R., Shinozuka, Y., McNaughton, C. S., Howell, S. G., Clarke, A. D., Emmons, L. K., Apel, E. C., Pfister, G. G., van Donkelaar, A., Martin, R. V., Millet, D. B., Heald, C. L., and Jimenez, J. L.: Evolution of Asian aerosols during transpacific transport in INTEX-B, Atmos. Chem. Phys., 9, 7257-7287, doi:10.5194/acp-9-7257-2009, 2009.

Favez, O., Alfaro, S., Sciare, J., Cachier, H., and Abdelwahab, M. M.: Ambient measurement of light-absorption by agricultural wast burning organic aerosols, Aerosol Sci., 40, 613-620, 2009.

FIRMS: Fire Information for Resource Managment Systems, edited by: Maryland, U. o., University of Maryland, available at: http: //maps.geog.umd.edu/firms/default.asp\#, 2009.

Garland, R. M., Yang, H., Schmid, O., Rose, D., Nowak, A., Achtert, P., Wiedensohler, A., Takegawa, N., Kita, K., Miyazaki, Y., Kondo, Y., Hu, M., Shao, M., Zeng, L. M., Zhang, Y. H., Andreae, M. O., and Pöschl, U.: Aerosol optical properties in a rural environment near the mega-city Guangzhou, China: implications for regional air pollution, radiative forcing and remote sensing, Atmos. Chem. Phys., 8, 5161-5186, doi:10.5194/acp-85161-2008, 2008.

Gyawali, M., Arnott, W. P., Lewis, K., and Moosmüller, H.: In situ aerosol optics in Reno, NV, USA during and after the summer 2008 California wildfires and the influence of absorbing and non-absorbing organic coatings on spectral light absorption, Atmos. Chem. Phys., 9, 8007-8015, doi:10.5194/acp-9-8007-2009, 2009.

Hand, J. L. and Kreidenweis, S. M.: A New Method for Retreiv- 
ing Particle Refractive Index and Effective Density from Aerosol Size Distribution Data, Aerosol Sci. Technol., 36, 1012-1036, 2002.

Hecobian, A., Zhang, X., Zheng, M., Frank, N., Edgerton, E. S., and Weber, R. J.: Water-Soluble Organic Aerosol material and the light-absorption characteristics of aqueous extracts measured over the Southeastern United States, Atmos. Chem. Phys., 10, 5965-5977, doi:10.5194/acp-10-5965-2010, 2010.

Hungershoefer, K., Zeromskiene, K., Iinuma, Y., Helas, G., Trentmann, J., Trautmann, T., Parmar, R. S., Wiedensohler, A., Andreae, M. O., and Schmid, O.: Modelling the optical properties of fresh biomass burning aerosol produced in a smoke chamber: results from the EFEU campaign, Atmos. Chem. Phys., 8, 34273439, doi:10.5194/acp-8-3427-2008, 2008.

IPCC: The Physical Science Basis. Contribution of Working Group! to the Fourth Assesment Report of the Intergovernmental Panel on Climate Change, edited by: Solomon, S., Qin, D., Manning, M., Chen, Z., Marquis, M., Averyt, K. B., Tignor, M., and Miller, H. L., Cambridge University Press, Cambridge, United Kingdom and New York, NY, USA, 2007.

Jacobson, M. Z.: Studying the effects of aerosols on vertical photolysis rate coefficient and temperature profiles over an urban airshed, J. Geophys. Res., 103(D9), 10593-10604, 1998.

Jacobson, M. Z.: Isolating nitrated and aromatic aerosols and nitrated aromatic gases as sources of ultraviolet light absorption, J. Geophys. Res., 104, 3527-3542, doi:3510.1029/1998JD100054, 1999.

Jacobson, M. Z.: Strong radiative heating due to the mixing state of black carbon in atmospheric aerosols, Nature, 409, 695-697, 2001.

Lack, D. A., Cappa, C., Baynard, T., Massoli, P., Covert, D., Sierau, B., Bates, T., Quinn, T., Lovejoy, E. R., and Ravishankara, A. R.: Bias in fliter based aerosol light absorption measurements due to organic aerosol loading: Evidence from ambient sampling, Aerosol Sci. Technol., 42, 1033-1041, 2008.

Lack, D. A. and Cappa, C. D.: Impact of brown and clear carbon on light absorption enhancement, single scatter albedo and absorption wavelength dependence of black carbon, Atmos. Chem. Phys., 10, 4207-4220, doi:10.5194/acp-10-4207-2010, 2010.

Lewis, K., Arnott, W. P., Moosmuller, H., and Wold, C. E.: Strong spectral variation of biomass smoke light absorption and single scattering albedo observed with a novel dual-wavelength photoacoustic instrument, J. Geophys. Res., 113, D16203, doi:16210.11029/12007JD009699, 2008.

Myhre, G.: Consistency Between Satellite-Derived and Modeled Estimates of the Direct Aerosol Effect, Science, 325, 187-190, 2009.

Noziere, B., Dziedzic, P., and Cordova, A.: The formation of secondary light-absorbing fluvic-like oligomers: A common process in aqueous and ionic atmospheric particles, Geophys. Res. Lett., 34, L21812, doi:10.1029/2007GL031300, 2007.

Posfai, M., Anderson, J. R., Buseck, P. R., and Sievering, H.: Soot and sulfate aerosol particles in the remote marine troposphere, J. Geophys. Res., 104, 21685-21693, 1999.

Ramana, M. V., Ramanathan, V., Feng, Y., Yoon, S.-C., Kim, S.W., Carmichael, G., and Schauer, J. J.: Warming influenced by the ratio of black carbon to sulfate and the black carbon source, Nature Geosci., 3, 542-545, 2010.
Ramanathan, V. and Carmichael, G.: Global and reginal climate change due to black carbon, Nature Geosci., 1, 221-227, 2008.

Ruiz-Morales, Y. and Mullins, O. C.: Measured and Simulated Electronic Absorption and Emission Spectra of Asphaltenes, Energy Fuels, 23, 1169-1177, 2007.

Schauer, J. J., Mader, B. T., Deminter, J. T., Heideman, G., Bae, M. S., Seinfeld, J. H., Flagan, R. C., Cary, R. A., Smith, D., Huebert, B. J., Bertram, T., Howell, S., Kline, J. T., Quinn, P., Bates, T., Turpin, B., Lim, H. J., Yu, J. Z., Yang, H., and Keywood, M. D.: ACE-Asia Intercomparison of a Thermal-Optical Method for the Determination of Particle-Phase Organic and Elemental Carbon, Environ. Sci. Technol., 37, 993-1001, 2003.

Schwarz, J. P., Spackman, J. P., Fahey, D. W., Gao, R. S., Lohmann, U., Steir, P., Watts, L. A., Thomson, D. A., Lack, D. A., Pfister, L., Mahoney, M. J., Baumgardner, D., Wilson, J. C., and Reeves, J. M.: Coatings and their enhancement of black carbon light absorption in the tropical atmosphere, J. Geophys. Res. Atmos., 113, D03203, doi:10.1029/2007JD009042, 2008.

Shapiro, E. L., Szprengiel, J., Sareen, N., Jen, C. N., Giordano, M. R., and McNeill, V. F.: Light-absorbing secondary organic material formed by glyoxal in aqueous aerosol mimics, Atmos. Chem. Phys., 9, 2289-2300, doi:10.5194/acp-9-2289-2009, 2009.

Stone, E. A., Schauer, J. J., Quraishi, T. A., and Mahmood, A.: Chemical Characterization and Source Apportionment of Fine and Coarse Particulate Matter in Lahore, Pakistan, Atmos. Environ., 44, 1062-1070, 2010.

Subramanian, R., Roden, C., Boparai, P., and Bond, T. C.: Yellow beads and missing particles: Trouble ahead for filter-based absorption measurements, Aerosol Sci. Technol., 41, 630-637, 2007.

Topping, D., Coe, H., McFiggans, G., Burgess, R., Allan, J., Alfarra, M. R., Bower, K., Choularton, T. W., Decesari, S., and Facchini, M. C.: Aerosol chemical characteristics from sampling conducted on the Island of Jeju, Korea during ACE Asia, Atmos. Environ., 38, 2111-2123, 2004.

UN-ECE: United Nations Economic Comission on Europe, available at: http://www.unece.org/env/lrtap, 2009.

Zhang, Q., Canagaratna, M., Jayne, J. T., Worsnop, D. R., and Jimenez, J. L.: Time- and size-resolved chemical composition of submicron particles in Pittsburgh: Implications for aerosol sources and processes, J. Geophys. Res. Atmos., 110, D07S09, doi:10.1029/2004JD004649, 2005.

Zhang, Q., Jimenez, J. L., Worsnop, D. R., and Canagaratna, M.: A Case Study of Urban Particle Acidity and Its Influence on Secondary Organic Aerosol, Environ. Sci. Technol., 41, 3213-3219, 2007.

Zhang, Y., Shun, S., Olsen, S. C., Dubey, M. K., and Dean, S.: CCSM3 simulated regional effects of anthropogenic aerosols for two contrasting scenarios: Rising Asian emissions and global reduction of aerosols, Int. J. Climatol., doi:10.1002/jpc.2060, in press, 2010.

Zhang, Y., Olsen, S. C., and Dubey, M. K.: WRF/Chem simulated impact of rising Asian emissions on air quality over North America, Atmos. Environ., 24, 2799-2812, 2010. 